\title{
PENDIDIKAN TERHADAP SISWA DITENGAH PANDEMI SERTA PENTINGNYA MENJAGA PROTOKOL KESEHATAN COVID-19 DI DESA WRINGIN BONDOWOSO
}

\author{
Ita Liana Ayuni' ${ }^{1}$ Muh Harawan Dimas Jakaria ${ }^{2}$ \\ 1Perbankan syariah, Fakultas Ekonomi dan Bisnis Islam, Institut Agama Islam Negeri Jember \\ ${ }^{2}$ Tadris Matematika, Fakultas Tarbiyah dan Ilmu Keguruan, Institut Agama Islam Negeri Jember \\ e-mail: italiana951@gmail.com¹, muh.harawan.dimas.jakaria@gmail.com²
}

\begin{abstract}
The implementation of the student education process during the pandemic is inseparable from the Health protocol. therefore, it is very important to ensure that the teaching and learning activities continue to run as they should. In this online learning, students are more required to learn independently, but in reality in the field students do not get adequate guidance, both from parents and teachers. This of course has an impact on the level of quality of education of students. The author uses a descriptive qualitative approach method in which the author describes and concludes problems related to the learning process and how to increase the sense of student spirit related to the learning process and how students can be independent in solving problems that occur during the covid-19 pandemic, both about general and religious learning and how important the implementation of education during the covid-19 pandemic while still understanding the rules of health protocols.
\end{abstract}

Keywords: education; students; covid-19

\begin{abstract}
Abstrak
Pelaksanaan proses pendidikan siswa pada masa pandemi ini tidak lepas dari protokol Kesehatan. oleh karena itu, sangatlah penting untuk memastikan agar kegiatan proses belajar mengajar tetap berjalan sebagaimana mestinya. Dalam pembelajaran daring ini, siswa lebih banyak dituntut untuk belajar mandiri, namun dalam realita di lapangan siswa tidak mendapatkan bimbingan yang memadai, baik dari orang tua maupun guru. Hal ini tentu saja berdampak pada tingkat kualitas Pendidikan siswa. Penulis menggunakan metode pendekatan kualitatif deskriptif dimana penulis mendeskripsikan dan menyimpulkan permasalahan yang terkait dengan proses pembelajaran dan bagaiman cara meningkatkan rasa semangat siswa terkait dengan proses belajar serta bagaimana siswa bisa mandiri dalam menyelesaikan permasalahan yang terjadi dimasa pandemi covid-19, baik tentang pembelajaran umum maupun keagamaan serta bagaimana pentingnya pelaksanaan pendidikan dimasa pandemi covid-19 dengan tetap memahami aturan protokol kesehatan.
\end{abstract}

Kata kunci: pendidikan;siswa;covid-19

\section{PENDAHULUAN}

Pendidikan adalah proses yang dilaksanakan dengan tujuan utama untuk mencerdaskan. Selain itu, pendidikan juga merupakan sebuah proses yang berperan besar bagi terciptanya sumberdaya manusia yang memiliki kualitas. Potensi peserta didik, baik dalam segi kekuatan spiritual keagamaan, kepribadian, pengendalian diri, akhlak mulia, kecerdasan, serta keterampilan yang dibutuhkan baik oleh dirinya sendiri, masyarakat, bangsa, dan negara, akan terwujud dengan terselenggarakannya proses pendidikan yang baik. Penerapan Pendidikan sangatlah berpengaruh terutama bagi siswa dimana masih diperlukannya bimbingan agar melatih potensi terhadap dirinya sendiri, apalagi dalam situasi pademi covid-19 yang tengah dialami pada saat ini. Banya negara yang menutup sekolah dan perguruan tinggi yang mengakibatkan aktivitas kegiatan belajar mengajar menjadi terganggu. 
Penyebaran virus corona ini sangat berdampak pada dunia pendidikan sehingga bagaimana kenyamanan belajar mengajar tetap terjaga dan berlanjut dalam waktu yang lama dan tidak melupakan pentingnya protokol kesehatan untuk memutus rantai penyebaran corona.

Menjaga kesehatan sangatlah penting bagi tubuh, terutama pada era pandemi covid19 ini dimana sesuai dengan anjuran dari pemerintah aturan yang diberlakukan sangatlah ketat, dilarang keluar dengan tidak menggunakan masker, menjaga jarak antar sesama dan sering cuci tangan bahkamn dianjurkannya berpakaian yang panjang. Dengan mengetahui adanya penerapan pendidikan siswa pada masa pandemi ini yang ternyata tidak lepas dari protokol kesehatan sangatlah penting untuk diperhatikan agar kegiatan belajar mengajar dapat tetap berjalan dengan lancar dan mengetahui kemampuan siswa dalam berpikir dan melatih dirinya terutama dengan metode pembelajaran yang sekarang berubah karena dampak pandemi dimana siswa yang lebih dituntut agar lebih belajar mandiri karena dalam hal ini, siswa tidak mendapatkan bimbingan secara langsung dan siswa merupakan pengaruh terbesar dalam kegiatan pembelajaran yang dijalankan dengan cara daring dan dengan tidak melupakan kewajiban sebagai warga negara yang taat aturan dengan tetap memperhatikan protokol kesehatan covid-19 agar lebih menjaga diri dan bersatu melawan untuk memutus rantai penyebaran c0vid-19, serta tidak hanya pendidikan umum akan tetapi diimbangi dengan pembelajaran tentang keagamaan agar dengan terjadinya pandemi ini siswa tidak meninggalkan kewajibannya sebagai umat muslim, dimana agar lebih meningkatkan kegiatan tentang keislaman serta menerapkan secara langsung dalam kegiatan sehari-hari.

\section{METODE}

Pengabdian ini dilakukan dengan menggunakan pendekatan kualitatif deskriptif. Metode pengumpulan data serta analisis yang dilaksanakan, memiliki tujuan mempelajari dan mengamati cara belajar siswa mengenai pembelajaran umum maupun tentang keagamaan yang mempelajari tentang keislaman di Masjid Baitul Muhlisin yang berada di desa Wringin Rt 02 Rw 11, ditengah Pandemi serta dengan ketentuan protokol kesehatan yang diterapkan ditengah masyarakat pada saat ini. Objek penelitian dalam kajian ini adalah teknik pembelajaran siswa dan kesadaran masyarakat dalam menerapkan protokol kesehatan dimasa pandemi covid-19. Pembelajaran siswa ini berbasis Home Schooling bagi pendidikan umum, yang terlaksana setiap hari dengan bimbingan mahasiswa KKN-DR yang berpotensi melatih siswa mandiri, kreatif, cakap, dan mudah berintegrasi antar sesama maupun lingkungan. Sedangkan pada pendidikan keagamaan lebi di tekankan pada kemandirian siswa dan pemahaman terhadap apa yang telah diajarkan. Penulis kemudian mengkolerasikan antara kegiatan belajar mengajar baik pendidikan umum maupun keagamaan dengan pentingnya semangat dalam manempuh pendidikan dalam kondisi dan situasi apapun terutama dalam masa pandemi covid-19 ini, tidak menjadi alasan untuk menunda pendidikan, hal tersebut guna membangun karakteristik pemuda yang berpendidikan sebagai penerus bangsa dan negara.

Metode pengumpulan data yang dilakukan dalam kegiatan ini adalah observasi dan dokumentasi. Observasi merupakan pengamatan dan pencatatan yang dilakukan dengan sistematik, terkait fenomena-fenomena yang sedang diselidiki. Metode ini dilakukan dengan tujuan untuk memperoleh data tentang siswa dengan metode pembelajaran yang baru dampak dari covid-19 baik pembelajaran secara umum maupun keagamaan, juga tentang kesadaran masyarakat bagaimana menerapkan hidup sehat dengan menaati protokol kesehatan covid-19. 
Analisis kualitatif deskriptif dipilih sebagai metode analisis data yang digunakan dalam kegiatan ini. Metode kualitatif adalah metode yang dimanfaatkan dalam menganalisis berbagai data yang bersifat kualitatif dengan menggambarkan menggunakan kata-kata dan kalimat berdasarkan kategori yang ada untuk memperoleh kesimpulan. Metode ini dipakai dalam proses analisis data-data yang berbentuk pernyataan-pernyataan, bukan kegiatan dan data yang berbentuk angka, dengan cara mengumpulkan dan melakukan analisis pada data-data tersebut, penulis Kemudian mendeskripsikan dan menyimpulkan pemecahan dari permasalahan mengenai pembelajaran dan rasa senang siswa dimasa pandemi covid- 19 baik tentang pembelajaran umum maupun keagamaan serta berhubungan dengan tentang pentingnya pendidikan dimasa pandemi covid-19 dengan tetap memahami aturan protokol kesehatan.

Peneliti juga menggunakan proses pemfokusan, yaitu sebuah proses yang merupakan bagian dari proses analisis yang bertujuan untuk mempertegas, memperpendek, dan membuang berbagai hal yang tidak terlalu penting, pelaksanaan proses dilakukan sepanjang proses penelitian dan pada saat pengumpulan data, selain itu, data yang telah dikumpulkan akan menjadi lebih fokus dan terkait dengan permasalahan yang ada. Kemudian pada tahapan penguraian data Penelitian, permasalahan dijabarkan sehingga kesimpulan dapat diperoleh.

\section{HASIL DAN PEMBAHASAN}

Sesuai dengan data yang diperoleh, teradapat beberapa permasalahan yang terjadi diantaranya pada sistem pembelajaran Home Shoolling dimana siswa tidak mendapatkan pemahaman materi secara penuh terhadap apa yang telah tertera yang menjadi kewajiban tugas mereka, selain itu pada pendidikan keagamaan terdapat permasalahan pada siswa sendiri dimana kurang pemahaman terhadap bahan ajar yang telah disampaikan, serta dimasa pandemi ini kurangnya kesadaran masyarakat untuk memahami protokol kesehatan. Tentunya pemasalahan yang terjadi diberikan berbagai alternatif yang berkaitan dengan masalahmasalah tersebut.

Siswa adalah subjek didik yang ditargetkan mampu mempunyai kompetensi sebagaimana yang sudah ditetapkan dalam standar kompetensi. Disinilah dengan dilakukannya analisis kemampuan awal dan juga karakteristik pada siswa akan mampu memberikan gambaran yang terperinci tentang bagaimana kemampuan siswa, hal ini tentunya berfungsi sebagai pandangan bagi adanya bahan baru yang disampaikan pada siswa. Selain itu analisis tersebut mampu mengukur tingkat penguasaan yang diperoleh siswa. Agar pemahaman terhadap materi bisa tersampaikan dengan jelas kepada para siswa, peneliti melakukan kegiatan belajar mengajar dengan menjelaskan menggunakan kata-kata yang diolah tersendiri sehingga mudah dipahami oleh siswa dengan bahasa dan pemahaman yang tidak begitu baku yang kemudian akan dijelaskan kembali tentang apa yang telah dikemukakan pada sebelumnya, sehingga mengajarkan siswa tidak takut dalam mengemukakan pendapat serta berani dalam menyampaikan materi dan memiliki wawasan berpikir yang luas.

Kemudian untuk pendidikan keagamaan, peneliti lebih menekankan pada kenyamanan siswa dalam belajar dan memahami materi, sehingga tidak terlalu kaku dalam proses berfikir dan memahami serta menghafal materi yang telah disampaikan bahkan untuk memperaktekkan dalam kehidupan sehari-hari akan lebih mudah. 
Sosialisasi dan edukasi dilakukan secara daring langsung pada masyarakat dengan tetap mematuhi protokol kesehatan. Salah satu yang mendapat sosialisasi dan edukasi ini pada masyarakat desa Wringin. Kesadaran masyarakat yang masih rendah akan bahayanya Covid-19 dan cara pencegahannya yang menjadi salah satu faktor utamanya. Himbauan yang disampaikan kepada masyarakat tentang pentingnya menjaga jarak antar sesama, menggunakan masker saat hendak keluar rumah, selalu mencuci tangan saat selesai melakukan aktivitas diluar rumah, dan juga dengan menggunakan poster atau pamflet dengan cara menyebarkan atau memperkenalkan pada tempat yang memang sering dikunjungi banyak orang seperti warga, toko, pinggir jalan raya, tiang atau pemahaman yang memiliki tempat strategis dan mudah terbaca oleh orang banyak.

Adapun hasil pelajaran yang diproleh selama pengabdian berlangsung dapat dilihat dari kondisi dan perilaku siswa itu sendiri dimana mengingatnya jumlah minat belajar anak baik tingkat Sekolah Dasar atau Taman Kanak-Kanak yang menunjukkan rasa percaya diri, cakap, kreatif dan pemberani dalam mengemukakan pendapatnya, serta dalam pendidikan keagamaan semakin bertambahnya jumlah minat mengaji siswa serta menghafal surat-surat pendek, doa sehari-hari, gerakan dan bacaan sholat, serta menulis dan membaca tulisan arab. Hal ini sesuai dengan teori yang dikemukakan oleh Sudirman (1988:75) yang mengemukakan: motivasi belajar merupakan seluruh kekuatan penggerak yang ada dalam diri siswa yang mampu memunculkan adanya kegiatan belajar, yang mampu menjamin terlaksananya kegiatan belajar dan juga memberikan arah pada kegiatan belajar tersebut, sehingga tujuan yang ingin dicapai oleh subjek belajar itu akan tercapai.

Tentunya hal tersebut tidak lepas dari penerapan protokol kesehatan selama pandemi. Dapat diperoleh data mengenai kesadaran masyarakat sekitar yang mulai berkembang terhadap aturan yang telah diberlakukan dengan tujuan memutus rantai penyebaran covid-19 yaitu meningkatkannya jumlah masyarakat yang sadar akan pentingnya memakai masker ketika hendak keluar rumah, serta penerapan jaga jarak antar sesama, bahkan sering mencuci tangan atau menggunakan handsanitizer ketika selesai dari tempat yang dikunjungi oleh banyak orang.

Pendidikan adalah kekuatan yang dapat memberdayakan dunia. Tanpa pendidikan tidak akan maju sebuah perdaban. Maka diwajibkan untuk melaksanakan pendidikan dasar selama 12 tahun guna memperkaya ilmu untuk kemajuan bangsa. Namun, saat ini yang semua rasakan adalah proses belajar mengajar di dunia pendidikan menjadi sedikit terhambat sejak munculnya Corona Virus Diseasean atau covid-19.

Pendidikan dasar saat ini dilakukan dengan cara Home Schoolling, pembelajaran yang dilakukan memberikan informasi atau penjelasan materi melalui tekhnologi digital. Kegiatan proses belajar mengajar dengan sistem dari rumah berlangsung semenjak tersebarnya virus corona yang mengharuskan murid tingkat SD dan TK di desa Wringin belajar dengan sistem daring. Kegiatan pembelajaran dilakukan setiap hari, pada pukul 08.00 WIB yang diikuti sekitar kurang lebih 7-9 oleh Murid SDN Wringin 02 dan Taman Kanak-Kanak Tunas Harapan desa Wringin Rt 03 Rw 04, Kecamatan Wringin, Kabupaten Bondowosos. Penelitian membimbing kegiatan belajar sekaligus mengamati perkembangan berpikir, keaktifan, dan interaksi mereka terhadap lingkungan. Kegiatan ini dilakukan setiap hari kecuali hari Sabtu dirumah saya sendiri desa Wringin RT 03 RW 04 Kec. Wringin kab. Bondowoso. Kegiatan ini dilakukan setiap hari agar siswa tidak bermalas-malasan terutama di era pandemi tidak ada alasan untuk melupakan kewajiban mereka sebagai seorang pelajar, dan juga agar tidak memutus perkembangan pendidikan sehingga sekolah yang diterapkan dari rumah. 
Pada pagi hari terlebih dahulu menjemput dulu murid yang dari Tingkat Sekolah Dasar karena bisa dibilang lumayan jauh perjalanan kerumah jika jalan kaki perjalanan ketempat pembelajaran yang merupakan tempat tinggal salah satu mahasiswa KKN-DR, dikarenakan mereka masih usia dini dan tidak baik jika berjalan tanpa ada yang mendampingi dan berpamitan keapada orang tua murid untuk membantu kegiatan belajar anak, hal tersebut dilakukan kepada semua murid yang belajar, baik tingkat Sekolah Dasar maupun Taman Kanak-Kanak. Kurang lebih sekitar 7 rumah kami mendatangi dan berpamitan dengan baik, bahkan ketika kegiatan sudah selesai kami pun juga memgantarkan semua murid ke rumah masing-masing kembali. Ketika semua murid sudah berkumpul, tak lupa mengajarkan bagaimana pentingnya untuk berdoa sebelum belajar, dan meminta agar salah satu dari mereka memimpin doa agar kegiatan proses belajar mengajar dapat dilakukan dengan lancar dan ilmu yang diperoleh bisa bermanfaat. Hal yang dilakukan memulai obrolan dengan bahasa mereka agar mereka merasa nyaman dan satu pemikiran sehingga pada saat belajar mereka lebih terbuka dan aktif ketika berinteraksi satu sama lainnya. Pertama mereka membaca terlebih dahulu tentang materi yang sudah diberikan oleh gurunya, kemudian dari kami berusaha untuk menjelaskan kembali dan jika ada hal yang tidak dipahami mereka bisa menanyakannya. Hal tersebut bagi murid tingkat Sekolah Dasar berbeda dengan tingkat Taman Kanak-Kanak, kami lebih menekankan untuk membaca bersama, menulis bersama, menghitung bersama. Hal tersebut dilakukan secara berulang agar mereka lebih memahaminya.

Di saat kondisi pandemi covid-19 yang ada, proses belajar mengajar, terutama yang terkait dengan pendidikan agama islam menjadi terhambat, hal tersebut mengakibatkan banyak orang tua mengeluh, pada satu sisi, orang tua kurang memiliki pemahaman dalam menggunakan media social, dan selain itu, banyak orang tua yang tidak memiliki kemampuan untuk mengajari atau membimbing anak anaknya terutama tentang ilmu-ilmu yang berkaitan dengan agama. Bagi seluruh umat muslim, pendidikan adalah hal yang terpenting yang ada di dalam kehidupan. Karena hanya dengan Pendidikan tersebut, manusia bisa memiliki kemampuan dalam menjaga kehidupan. Pada dasarnya, proses pendidikan bisa di maknai sebagai kekuatan yang bersifat dinamis yang ada dalam kehidupan setiap indivu. Hal ini kemudian menjelaskan bahwa adanya pendidikan tersebut dapat mempengaruhi aspek perkembangan fisik, emosional, social, dan mental dalam diri seorang anak.

Dalam hal pendidikan keagamaan, Madrasah Diniyah Al-Wafa merupakan sekolah islam yang berada di desa Wringin Rt 02 Rw 11, Kecamatan Wringin, Kabupaten Bondowoso, Jawa Timur. Madrasah diniyah yang berada dibawah naungan Ustadz Ris yang didirikan pada tahun 1995. Sebelum merintis keagamaan, ustadz Ris sendiri sudah menempuh jalan pendidikan agama, baik secara formal maupun non-formal. Kegiatan belajar atau mengaji pada Madrasah Al-Wafa ini dilakukan di Masjid Baitul Muhlisin yang memang sudah lama di bawah naungan ustadz Ris yang pada sebelumnya dirintis oleh Ustadz Surahman yang menjadi pengasuh pertama di Masjid Baitul Muhlisin dan Madrasah Diniyah AI-Wafa. Murid madrasah yang berada di bawah naungan ustadz Ris kurang lebih 30 orang.

Motivasi awal perintisan menjadi guru ngaji di masjid Baitul Muhlisin berawal dari kegelisahan yang dirasakan oleh Ustadz Surahman mengamati keadaan di lingkungan sekitar yang dirasa wawasan keagamaannya masih sangat minim. Selain itu, beliau mendapat dorongan untuk terus berdakwah dalam rangka menyebarkan ilmu, dan juga dengan niatan ber-amar ma'ruf nahi mungkar, supaya tatanan masyarakat yang lebih baik mampu terwujud kedepannya. Dikarenakan Ustadz Surahman mulai sepuh dan digantikan oleh anaknya yaitu Ustadz Ris yang sehingga saat ini menjadi pengasuh Masjid Baitul Muhlisin. 
Kegiatan berlangsungmulai pukul 02.00 siang sampai pukul 04.00 sore. dimulai Kegiatannya murid-murid berbaris dan belajar bacaan serta gerakan sholat yang benar, disana memperhatikan bacaan apa dan gerakan apa yang kurang sesuai, kemudian membetulkannya, hal tersebut berlangsung dari awal bacaan dan gerakan hingga akhir. Kemudian dilanjutkan dengan kegiatan membaca doa-doa, susudah sholat, setelah selesai Kemudian diawali dengan pembacaan doa sebelum belajar. Kemudian murid-murid dibagi menjadi 3 bagian agar lebih efektif dalam proses pembelajaran, dimana murid yang lebih kecil lebih mendasar pelajarannya. Lalu menulis di papan tulisan Al-Qur'an dan murid-murid lainnya menulis kemballi di buku dan dinilai oleh ustadzah, kemudian mereka membaca bersama bacaan dipapan, dan maju satu persatu untuk membaca kembali bacaan Al-Qur'an panjang dan pendeknya bacaan serta cara pembacaan makhrijul huruf.

Ketika semua murid-murid sudah mendapatkan bagian, kemudian duduk sembari menunggu murid-murid lainnya mendapatan gilira. Dan ketika semua sudah slesai dilanjutkan dengan membaca doa dan surat-surat pendek kemudian menunggu giliran untuk dipanggil kedepan bersalaman dan diperbolehkan pulang kerumah masing-masing.

Pembelajaran pada masjid Baitul Muhlisin tetap berjalan seperti biasanya dengan cara bertatap muka langsung, dikarenakan pada era sekarang memasuki new normal dan pada lingkungan tersebut dalam keadaan aman, maka ustadz Ris selaku pengasuh memberlakukan kembali kegiatan madrasah diniyah yang meman pada awalnya sempat tertunda akibat maraknya covid-19, semua diberlakukan sebagagimana mestinya akan tetapi tetap dengan memperhatikan prosedur protokol kesehatan, seperti mencuci tangan sebelum memasuki masjid.

Tidak lepas dari itu, maraknya covid19 semakin merajalela, mahasiswa KKN membuat pamflet dan menyebarkannya di sekitar desa wringin. Agar kesadaran masyarakat dalam menjaga kesehatan dan kebersihan tetap terjaga dan menjadi suatu kewajiban mematuhi aturan yang diberlakukan seperti halnya wajib memakai masker ketika hendak keluar rumah. sekitar pukul 08.30 berjalan kaki ke tempat yang sering didatangi oleh orang banyak, seperti pinggir jalan raya, warung-warung, toko serta menempelkan di depan gang dan pepohonan.Melakukan penyebaran pamflet dengan bertujuan agar warga lebih terfokus untuk membacanya serta menerapkan penggunaan wajib masker, sering mencuci tangan, menjaga jarak antar sesama dan menjaga imun agar tetap sehat. Dan ketika ada orang yang lewat maka sedikit menjelaskan bagaimana pentingnya menerapkan hal-hal yang telah tertera di pamflet untuk bersatu melawan Corona.

Serta diimbangi dengan pembagian handsanitizer kepada masyarakat sekitar, agar tetap menjaga kebrsihan tangan, karena 99\% pennyebaran virus corona melalui tangan. Handsanitizer merupakan sejenis cairan yang pada umumnya dimanfaatkan untuk mengurangi adanya kuman, atau patogen pada tangan. Penggunaan cairan pensanitasi tangan yang berbasis alkohol cenderung lebih disukai dibandingkan mencuci tangan dengan menggunakan sabun pada berbagai kondisi di tempat pelayanan kesehatan. mencari daun sirih sebagai bahan utama pembuatan Handsanitizer secara herbal, serta memberitahukan kepada warga bahwasannya Handsanitizer juga dapat di gunakan dengan bahan dasar daun sirih. Karena terbukti daun sirih memiliki kandungan antiseptik pembersih kuman. Lalu mengolahnya dengan cara di layukan terlebih dahulu kemudian merebus dan menyaringnya. Dicampurkan dengan sedikit garam lalu menyiapkan botol bekas yang sudah tidak dipakai dan menyaringnya dan memasukkan ke dalam botol dan Handsanitizer siap dibagikan kepada warga sekitar. Kami membagikannya kepada warga yang berada dipinggir jalan raya, 
utamanya yang sering dikunjungi oleh banyak orang seperti warung dan toko bensin. Membagikan handsanitizer serta menjelaskan fungsi dari Handsanitizer tersebut dan bahan utama yang digunakan agar mudah membuat sendiri di rumah dan sering menggunakan sebagai antiseptik sementara.

\section{KESIMPULAN}

Melalui proses pendidikan yang berperan besar untuk menciptakan sumberdaya manusia yang berkualitas. Objek penelitian dalam kajian ini adalah teknik pembelajaran siswa dan kesadaran masyarakat dalam menerapkan protokol kesehatan dimasa pandemi covid-19. Pembelajaran siswa ini berbasis Home Schoolling. dimana siswa tidak mendapatkan pemahaman materi secara penuh terhadap apa yang telah tertera yang menjadi kewajiban tugas mereka, selain itu pada pendidikan keagamaan terdapat permasalahan pada siswa sendiri dimana kurang pemahaman terhadap bahan ajar yang telah disampaikan, serta dimasa pandemi ini kurangnya kesadaran masyarakat untuk memahami protokol kesehatan sehingga diberikan alternatif penyelesaian sehingga mengingatnya jumlah minat belajar anak baik tingkat SD atau TK yang menunjukkan rasa percaya diri, cakap, kreatif dan pemberani dalam mengemukakan pendapatnya, serta dalam pendidikan keagamaan semakin bertambahnya jumlah minat mengaji siswa serta menghafal surat-surat pendek, doa sehari-hari, gerakan dan bacaan sholat, serta menulis dan membaca tulisan arab dan meningkatkannya jumlah masyarakat yang sadar akan pentingnya memakai masker ketika hendak keluar rumah, serta penerapan jaga jarak antar sesama, bahkan sering mencuci tangan atau menggunakan handsanitizer ketika selesai dari tempat yang dikunjungi oleh banyak orang. Tentunya pemasalahan yang terjadi diberikan alternatif atau penyelesaian dengan cara sosialisasi dan edukasi terhadap masyarakat serta menganalisis kemampuan dan karakteristik siswa.

\section{DAFTAR PUSTAKA}

AR Chaerudin, Bambang Setiadi, \& Ahmad Munawir. (2020). PEMBERDAYAAN EKONOMI MASYARAKAT BERBASIS EKONOMI KREATIF DI DESA CITAMAN KECAMATAN CIOMAS KABUPATEN SERANG BANTEN. Jurnal Abdimas Bina Bangsa, 1(1), 26-37. doi:10.46306/jabb.v1i1.9

Hasria Alang, Eka Apriyanti, \& Hartini. (2020). EDUKASI KESEHATAN REPRODUKSI SECARA DARING PADA SISWI SD DALAM RANGKA MENGHADAPAI MANARCHE. Jurnal Abdimas Bina Bangsa, 1(2), 186-193. doi:10.46306/jabb.v1i2.26

Kholik, Rusi Rusmiati, Widyasari, dan Syamsudin. 2017. Pengantar Ilmu Pendidikan. Jawa Barat:Unida Press

Laylatul Hasanah, Sri Sumarni, \& Eko Mulyadi. (2020). A PENDAMPINGAN PENCEGAHAN PENYEBARAN COVID - 19 DI DESA ERRABU KECAMATAN BLUTO KABUPATEN SUMENEP. Jurnal Abdimas Bina Bangsa, 1(1), 71-77. doi:10.46306/jabb.v1i1.11

Rumetna, M. S., Ninia Lina, T., Reza Tauran, L., Sitorus, N., Patty, T., Malak, A., ... Orisu, N. (2020). PENDAMPINGAN DAN PELATIHAN PENERAPAN METODE SIMPLEKS PADA USAHA DAGANG BINTANG TIURMA. Jurnal Abdimas Bina Bangsa, 1(2), 205214. doi:10.46306/jabb.v1i2.28

Sintong Silaban. 1993. Pendidikan Indonesia dalam Pandangan Lima Belas Tokoh Pendidikan Swasta, Bagi IV , Jakarta: Dasa Media Utama 